\title{
Avicenna's Proof of the Existence of God: Problem 7
}

In Section 7 of the Shukūk, al-Mas'ūdī targets Avicenna's well-known cosmological argument from possibility for the existence of the First Cause, God. In what follows, we begin with a reading of the proof as it appears in the Ishärät, referring where relevant to the corresponding discussion in the Najät, and then make a quick detour to the Shifä, where Avicenna addresses a closely related puzzle. We then consider al-Ghazālī's objections to the proof, before turning to the complaint raised by al-Mas'ūdī.

\subsection{Avicenna's Proof from Possibility}

The proof of the existence of the Necessary of Existence through Itself appears in Chapter 4 of the Physics and Metaphysics of the Ishärät (II.4.9-15). ${ }^{1}$ Following a discussion of causation, Avicenna introduces the concepts 'possible existent' and 'necessary existent', and submits that every existent must be either possible of existence in itself, or necessary of existence in itself (Ishärāt II.4.9). ${ }^{2}$ A thing that is possible in itself is predisposed as such to neither existence nor nonexistence. So if such a thing becomes existent, there must be something other than itself that tips the balance and renders its existence preponderant to its nonexistence. Therefore, the existence of a possible thing must be caused by another (Ishārāt II.4.10). ${ }^{3}$ What Avicenna intends by 'cause' here is a 'metaphysical' efficient cause (that is, a cause of existence), as opposed to a 'physical' efficient cause (that is, a cause of motion). ${ }^{4}$ As such, the cause of a possible existent must coexist with its effect. ${ }^{5}$

1 Avicenna, Ishärāt, 3, 19-27. For a discussion of the proof as it appears in the Najāt, see McGinnis, Avicenna, 163-168.

2 Avicenna, Ishärāt, 3, 19.

3 Avicenna, Ishärāt, 3, 20.

4 On this distinction, see Section 3.2 above.

5 This reading finds explicit confirmation in the Najāt (567; cf. Davidson, Proofs for Eternity, $299 \mathrm{ff}$.). In his commentary on the proof as it appears in the Ishārāt, al-Rāzī rightly points out that it lacks a vital ingredient—namely, an indication of whether the series of successive causes possible of existence are ordered temporally, or are simultaneous. He writes that 
Now, it is obvious that possible existents do actually exist. Each possible existent must be caused either by another possible existent, or by an existent necessary through itself. As the existence of the latter has yet to be demonstrated, the argument proceeds on the assumption that the cause is a possible existent. If this second possible existent is caused by yet another possible existent, which is caused by yet another possible existent, then the series of successive causes possible of existence may be either infinite or finite. The next passage (Ishärāt II.4.11), therefore, begins with the disjunctive 'either' (immā), although Avicenna here only considers the former disjunct, namely that the series is infinite (which is why, in what follows, I have replaced 'either' with 'if'). He writes:

If [the series of causes possible of existence] regresses ad infinitum, then each unit in this series will be possible in itself. The whole (jumla) is dependent on these [units]. Therefore, it too is not necessary, but must be necessitated by another. ${ }^{6}$

The second disjunct - that the series of causes possible in themselves is finite-is omitted, as it points straightforwardly to the existence of an ultimate cause necessary through itself. ${ }^{7}$ What is deserving of consideration is only the notion that the series of causes possible of existence could regress ad infinitum, which ostensibly would leave no room for an ultimate, first cause. Both disjuncts are mentioned in the Najāt. ${ }^{8}$

Avicenna 'ought to have explained, prior to this section [Ishärāt II.4.11], that the efficient cause cannot precede its effect in time. For if it is possible [for the cause to precede its effect in time], it would not be impossible for every possible thing to be dependent on another preceding it in time, ad infinitum. However, according to him, this is not impossible' (Sharh, 2 , 346). The question of whether or not the series of temporally successive occurrences is beginningless is of no relevance to Avicenna's proof for the existence of the Necessary of Existence through Itself; and, in fact, the discussion centres on the concept of 'possibility' and makes no reference to 'coming-to-be'. So, as al-Rāzī adds, the precise question Avicenna needs to address is whether or not an infinite series of simultaneous causes exist. Al-Rāzī opines that this is the place in which Avicenna ought to have addressed this question, but excuses him since he returns to it in Ishärät II.5.1-3, as we have already seen in Chapter 3 (Sharh., 2, 346-347). So I differ with Toby Mayer, who takes the series to be temporally ordered, and reads al-Rāzī's attempt to develop Avicenna's argument as a misreading motivated by a theological agenda ('Ibn Sīnā’s Burhān', 28 ff.).

6 Avicenna, Ishārät, 3, 21.

7 Cf. al-Rāzī, Sharh, 2, 347.

8 Avicenna, Najāt, 567 . 
The point that Avicenna makes here is that a hypothetical series consisting of an infinite number of possible things constitutes a whole, and in this respect can be treated as a self-contained set. As such, the series must be in itself either necessary or possible. It cannot be necessary through itself; for the whole depends on its constituent parts, in the sense that it exists through their existence, and the parts in this case are all possible of existence. Therefore, the whole, like its parts, must be possible of existence. And since it has already been established that what is possible of existence must be caused by another, it follows that the whole must be caused by something other than itself.

The upshot of the argument is that even a series that consists of an infinite number of causes possible of existence and includes absolutely all such causes must, as a whole, have a cause that falls outside it. This cause cannot be possible of existence, but must be something necessary of existence in itself. What Avicenna concludes here is effectively that even if an infinite series of possible causes is postulated, it cannot be self-sufficient with respect to its existence; for if this infinite series is 'bracketed' and considered as a self-contained whole, it must depend ultimately on a cause necessary of existence, beyond which no further cause exists. Avicenna's proof for the existence of the First Cause concludes with the statement, "Therefore, every series terminates (tantahī) in the Necessary of Existence through Itself' (Ishārāt II.4.15). ${ }^{9}$ Which implies that Avicenna's proof for the existence of God can be read as a reductio ad absurdum, whereby the starting hypothesis (the series is infinite) is shown to be impossible (the series must terminate at some point, and hence must be finite). This conclusion is spelled out explicitly in the Najät:

Therefore, possible existents must terminate in a cause that is necessary of existence. It follows that not every possible existent has a simultaneous cause possible of existence. Therefore, it is impossible for an infinite number of causes to exist together at the same time. ${ }^{10}$

To highlight the novelty of his train of reasoning, Avicenna is careful to keep the existence of the First Cause independent of the finitude of causes possible of existence. A little later in the Ishärät (II.4.29), he refers back to this proof (and subsequent discussions) as follows:

9 Avicenna, Ishārāt, 3, 27.

10 Avicenna, Najāt, 568; cf. Ilāhiyyāt, VIII.1, 327-329. 
Reflect on how our proof for the existence and oneness of the First and His being free from attributes did not require reflection on anything except existence itself and how it did not require any consideration of Its creating and acting, even though these do attest to [Its existence and nature]. This mode, however, is more reliable and noble, that is, when we consider the state of existence, we find that existence inasmuch as it is existence bears witness to It, and afterwards It bears witness to all that comes after It in existence. ${ }^{11}$

The novelty of the argument lies in that it does not prove the existence of the First Cause starting from the finitude of the series of causes possible of existence. Instead, it first establishes that the First Cause exists, and then infers that the series of causes possible of existence must be finite.

$$
\begin{gathered}
\mathrm{P}_{\infty} \ldots \rightarrow \mathrm{P}_{3} \rightarrow \mathrm{P}_{2} \rightarrow \mathrm{P}_{1} \\
\mathrm{~N} \rightarrow\left\{\mathrm{P}_{\infty} \ldots \rightarrow \mathrm{P}_{3} \rightarrow \mathrm{P}_{2} \rightarrow \mathrm{P}_{1}\right\} \\
\mathrm{N} \rightarrow\left\{\mathrm{P}_{\mathrm{n}} \ldots \rightarrow \mathrm{P}_{3} \rightarrow \mathrm{P}_{2} \rightarrow \mathrm{P}_{1}\right\}
\end{gathered}
$$

An illustration of Avicenna's 'bracketing' of an infinite series of possible things. $P_{1}$ is caused by $P_{2}$.

The above-quoted passage (Ishārät II.4.11) concludes with, 'Let us explain this further'.12 So the next passage is labelled 'explanation' (sharh). What it explains is the notion that if all the constituent units of a whole are caused, the whole too must itself be caused by another-that is, by something other than its units-regardless of whether the units are finite or infinite in number. The passage goes as follows (Ishärāt II.4.12):

Every whole, whose units are each caused, will itself require a cause that is other than its units. For either $[a]$ [the whole] does not require a cause at all, in which case it will be necessary, rather than possible. However, how could it be so, when it can only be necessitated by its units!

Or $[b]$ it requires a cause, which is the entirety of the units, in which case it will be caused by itself; for the whole and the totality (al-kull) are one and the same thing. As to 'the totality' in the sense of 'each unit' (kull wähid), this will not necessitate the whole.

\footnotetext{
11 Avicenna, Ishārāt, 3, 54 (Marmura's translation in 'Avicenna's Proof', 133, with adjustments).

12 Avicenna, Ishārāt, 3, 22.
} 
Or $[c]$ it requires a cause, which is some of its units. However, none of its units would be more predisposed $(a w l \bar{a})$ than the others to be [the cause of the whole]. For each one of [its units] is caused, and its cause will be better predisposed in that way.

Or $[d]$ it requires a cause other than all its units. This is the remaining [division in the elimination process]. ${ }^{13}$

From this elimination argument, Avicenna goes on to conclude that the thing that causes the whole of all causes possible of existence must be a terminus (taraf), that is to say, an uncaused cause, as opposed to an intermediate thing (wasat), which is both caused and a cause for another. This uncaused cause must be necessary in itself. ${ }^{14}$

In Ishārāt II.4.14, Avicenna then considers a series that does not consist exclusively of possible, and hence caused, things. If a series includes things that are all caused, except one which is an uncaused cause, this uncaused cause must be a terminus for the series, rather than an intermediate link within it, and as such it would be the ultimate cause for the rest of the series. Again, this ultimate cause cannot be possible, but must be necessary in itself. ${ }^{15}$ In all cases, therefore, there must be a thing that is necessary of existence through itself, and the ultimate cause of possible existents.

\subsection{Avicenna on Infinite Temporal Series}

Avicenna was well-aware that the same reasoning through which he infers that a series of simultaneous causes must terminate in an uncaused cause can also be used to infer that a series of temporally ordered causes must terminate in a first, pre-eternal cause preceded by no further causes. As already noted, the former series would consist of what Avicenna considers to be 'metaphysical' causes, whereas the latter would consist of what he terms 'physical' causes. ${ }^{16}$ So in the Physics of the Shif $\tilde{a}$, he confutes several arguments adduced against the doctrine of a beginningless series of temporally ordered occurrences, a discussion pertinent to the question of when a series constitutes a whole.

In his response to the first objection, Avicenna makes clear that unlike a series of coexistent things, a series of temporally ordered items, in which

\footnotetext{
13 Avicenna, Ishārāt, 3, 23-24.

14 Avicenna, Ishārāt, 3, 27.

15 Avicenna, Ishārāt, 3, 26-27.

16 See Section 3.2 above.
} 
items come to be and pass away in succession, does not constitute a whole. The objection in question is John Philoponus's well-known argument from the increase and decrease of infinite quantities, which came to be known as the argument from correspondence (burhān al-tațbiq). ${ }^{17}$ As presented by Avicenna, it runs as follows. If we postulate a beginningless series of successive motions, and if we then consider the number of motions that occurred up to the Flood, and those that occurred up to the present day, the former quantity will be smaller. If a quantity is smaller than an infinite quantity, then the former quantity must be finite; however, this contradicts the initial assumption that it is infinite. Our initial postulate, therefore, is unsustainable..$^{18}$ Avicenna responds by arguing that, when considered in the present, past motions will be non-existent, and hence will not cumulate into an actual infinite quantity. What is realised, therefore, is not the series of past occurrences as such, but rather each past occurrence individually. He adds:

Yet the status of each one is not that of the whole (kulliyya) of the past. [...] The fact is that all the finite number of things that have been or will be realised, and are such that the second follows upon the first's ceasing to exist, do not constitute a whole ( jumla). For what is understood by 'whole' is the aggregation $\left(\ddot{j} t i m \bar{a}^{c}\right)$. These are, however, simply not collected together in reality, even if each one of them exists individually at some moment during which the other does not exist. ${ }^{19}$

Successive past occurrences exist together only in the mind. Being transitory, they do not constitute an aggregate and have no real totality, and hence no quantity, in the external world. So the coming-to-be of further occurrences does not result in an infinite coexisting quantity.

In response to a further objection, Avicenna contends that since a temporal series such as the one described does not constitute a whole, the series lacks any real attributes. The objection is that if every motion comes to be in time, the whole $(k u l l)$ and totality (jumla) of motions come to be in time. ${ }^{20}$ In other words, since all the individuals share the attribute of being temporally originated, the whole too must have the same attribute. This claim unmistakably

17 See, for instance, Philoponus, Against Aristotle, 145-146; Davidson, Proofsfor Eternity, 86 ff., esp. 88-89.

18 Avicenna, Țabīicyyāt, I.III.11, 365 .

19 Avicenna, Tabǐìyyāt, I.III.11, 367 (McGinnis's translation, with modifications).

20 Avicenna, Țabīìyyät, I.III.11, 365 . 
parallels Avicenna's assertion that the totality of things possible of existence must, as a totality, be possible of existence, the difference being that 'possibility' here is swapped for 'coming-to-be'. Consistency demands, it seems, that Avicenna treat a chain of temporally ordered causes no differently than he treats a chain of simultaneous causes. In response, he counters that even where individuals, all sharing the same attribute, do make up a whole, the whole need not be characterised by that attribute. Moreover, in the case under discussion, the individuals do not even add up to an actual whole, as Avicenna argues reiterating his earlier point. It follows that a series of occurrences that come to be and pass away, one after the other, cannot bear any attributes, as a set, over and above the attributes borne by each of its constituents individually. ${ }^{21}$

\subsection{Al-Ghazālī’s Criticism}

Avicenna's proof for the existence of the Necessary of Existence is targeted in the Fourth Discussion in al-Ghazālī's Tahāfut, titled 'On showing [the philosophers'] inability to prove the existence of the maker of the world'. In the course of his criticism, he reports the argument that if all possible things are considered as a whole, the whole too will be possible and will require a cause that is not possible, but necessary. ${ }^{22} \mathrm{Al}-\mathrm{Ghaza} l \bar{i}$ complains that the expressions 'necessary' and 'possible' are vague, but he is willing to put up with them as long as the former is defined as 'uncaused', and the latter as 'caused'. By these definitions, however, although each individual in a hypothetical infinite series of causes will be possible in the sense of being produced by another, the totality of the series will not be produced by another- that is, by a cause that lies outside the series-and hence it is not possible in this sense. ${ }^{23}$

This response implies that, in the case hypothesised, something necessary (that is, the whole series, since it is uncaused) subsists through possible things. Al-Ghazâlī concedes this implication-provided that 'necessary' and 'possible' are defined in the sense indicated-on the principle that what is true of the individuals need not, by extension, apply equally to the totality $\left(\right.$ majmü $\left.^{c}\right)$. This general principle was most probably picked up from Avicenna's discussion of temporal series, where he makes exactly the same point, as we have just

\footnotetext{
21 Avicenna, Țabĩiyyāt, I.III.11, 368-369 (McGinnis's translation, with a slight modification).

22 Al-Ghazālī, Tahāfut, $138 \mathrm{ff}$; for a discussion of al-Ghazālī's criticism, see Davidson, Proofs for Eternity, $366 \mathrm{ff}$.

23 Al-Ghazālī, Tahāfut, 138-139.
} 
seen. To substantiate this principle, al-Ghazālī uses an ad hominem (ex concessis) argument (ilzäm), which analogises the chain of simultaneous causes to chains of temporally ordered occurrences. For instance, time, according to the philosophers, is pre-eternal, yet it subsists through motions, each of which comes to be in time. Al-Ghazālī remarks: 'Therefore, that which has no beginning has been rendered subsistent by things that have beginnings; and "having a beginning" is true when said of individual units, but not true of the totality'. ${ }^{24}$ It follows that the whole need not carry the same attributes as its individual parts. Al-Ghazāli concludes that since the philosophers consider the series of past occurrences beginningless, although each occurrence comes to be in time, they are not entitled to hold that a series of simultaneous causes must be finite, and correspondingly that a First Cause exists. In his view, the difference ( farq) that his adversaries make between the two cases is purely arbitrary (tahakkum mahd $)^{25}$

Al-Ghazāli then considers Avicenna's aforementioned response to the argument from correspondence, that past occurrences exist, not simultaneously, but in temporal succession, and hence do not exist as an actual infinite in the external world, though such an infinite quantity can be hypothesised in the estimation (wahm). He counters by pointing out that Avicenna does in fact affirm an actual infinity, namely the infinite number of souls of deceased humans, which are indestructible and hence cumulate in actual existence despite the corruption of the bodies to which they were attached. ${ }^{26} \mathrm{~A}$ little earlier in the same Fourth Discussion in the Tahăfut, al-Ghazāli had already rebuffed Avicenna's contention that an actual infinity is only impossible if its constituent items are ordered in either position or nature, whereas human souls do not exist in any specific order in relation to each other, and therefore can be infinite in number. This, al-Ghazālì complains, is an unsubstantiated claim, as Avicenna fails to demonstrate that an actual infinite is impossible only if it consists of a chain ordered in either of these ways. Moreover, it is arguable that human souls are ordered according to the time of their coming-to-be, and that consequently there is no difference between an infinite number of coexisting causes and an infinite number of coexisting souls. ${ }^{27}$

\footnotetext{
24 Al-Ghazālī, Tahāfut, 139.

25 Al-Ghazālī, Tahāfut, 140.

26 Al-Ghazālī, Tahāfut, 141.

27 Al-Ghazālī, Tahăfut, 137; cf. Marmura, 'Avicenna and the Problem of the Infinite Number of Souls'.
} 


\subsection{Al-Mas'ū ūì's Commentary}

A version of Avicenna's proof appears in al-Mas'ūdī's commentary on Avicenna's al-Khutba al-gharrä'. If we consider the totality (jumla) of existents, the argument goes, then either they include an existent that is necessary through itself, or they do not include such an existent. If the former, then there exists a thing that is necessary through itself, which is what we are after.

However, if the totality of existents does not include such an existent, but is such that the existence of any given existent is produced by another, and the existence of that other is produced by another, and the existence of that other is produced by yet another, and so on and so forth ad infinitum, then each individual within the totality of existents will be caused in itself, and its existence will be produced by a cause that precedes its existence. So the whole and totality of existents, qua a single whole, must be caused. For it obtains from caused individuals, and the whole that obtains from caused individuals is, by necessity, itself caused and not necessary of existence through itself. Then the cause of a caused whole must be either [1] the totality of its [constituent] individuals, or [2] each one of these individuals, or [3] a specific one of these individuals, or [4] something other than these individuals and their totality. ${ }^{28}$

Each division is then eliminated in turn. The cause cannot be the totality, for otherwise the totality of caused individuals would be necessary of existence through itself. Nor can it be each one of its individual constituents, for if the whole is caused by one individual it cannot conceivably be caused by another. Nor can the cause be one constituent, for since all constituents are caused, it would be a cause for its own existence and the existence of its own cause. Nor can the cause be outside the totality, for the totality was postulated to include the entirety of existents. Therefore, the postulate that all existents are caused must be false; and the contrary must be the case, namely that there must be something in existence that is uncaused and is the ultimate cause of other existents.

Notwithstanding, in Section 7 of the $S h u k u ̄ k$, al-Mas' $\bar{u}$ dì raises an objection to the argument. Quoting Ishārāt II.4.12, the elimination argument quoted earlier in the present chapter, he opens his commentary by briefly explaining that the passage intends to prove that the series of causes must be finite, and

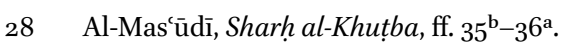


ultimately that a thing that is necessary through itself exists. There is nothing in the passage itself with which he disagrees: he accepts the principle that a whole, each of whose constituent units is caused, must itself be caused, and that its cause must be external to it; so he should have no quarrel with the elimination argument through which this principle is established. What he challenges, rather, is that this principle could apply to an infinite quantity of units (as claimed in Ishārāt II.4.11, quoted above), as follows:

A. A whole, each of whose constituent units is possible, must itself be possible.

B. An infinite series of possible things is a whole, each of whose constituent units is possible.

C. Therefore, an infinite series of possible things is itself possible.

Al-Mas'ūdī targets the minor premise $\mathrm{B}$, which, he contends, remains unproven, since Avicenna fails to support it with any substantiating proof. ${ }^{29} \mathrm{He}$ has no objections to the major premise A, the focus of al-Ghazālī's attack, as we have already seen.

An adversary (khașm) of Avicenna, al-Mas'ūdī argues, can dismiss premise $B$ as false simply on the grounds that an infinite quantity of things do not make up a whole. Being 'a whole' (jumla, kull, jami ) is an accident concomitant to things of finite quantity. For the definition of 'the whole' of all Xs is the totality $(m a j m \bar{u})$ of all individual Xs, which does not leave out any Xs. ${ }^{30}$ There must be an extremity, or a limit (hadd) at which Xs end, so that the totality of what falls within these limits (mahdūd) constitutes a whole. ${ }^{31}$ However, if an infinite series of coexisting causes is hypothesised, they can have no bounded, all-encompassing totality; for whatever totality we may postulate, there will be further causes beyond it in the series. So if an infinite quantity of successive things, each caused by the thing preceding it and the cause of the thing succeeding it (except for one thing, which is caused but not a cause), do not make up a whole, there will be no whole to which the causedness of each unit in the series can be extended, and which hence can be said to be caused.

The upshot of the objection is that Avicenna implicitly premises his argument on precisely the view that the argument seeks to prove. By treating the series as a 'whole', he has already determined it to be finite. So it is no surprise

\footnotetext{
29 Shukūk, 248.

$30 S h u k u \bar{k}, 248$. I have not found this definition in Avicenna.

31 Shukūk, 249.
} 
that his reductio argument seems to show that even if a series of coexisting things is hypothesised as infinite, it necessarily is finite.

Al-Mas'ūdī supports this central objection with an ad hominem (ex concessis) argument, which appeals to the same cases of infinity affirmed by Avicenna that al-Ghazâlī uses in his refutation. He appeals to them, however, within a new line of argument. For al-Ghazālī, these cases illustrate that Avicenna is inconsistent in his application of the principle that what applies to all individuals applies equally to the whole, and in doing so they bring premise A into question. Al-Mas'ūdī invokes them against premise B, his argument being that in other cases Avicenna does not treat infinite quantities as wholes. ${ }^{32} \mathrm{His}$ ad hominem argument takes the form of an analogy starting from cases in which all Xs share a certain attribute, but the attribute is not extended to the totality of Xs. According to al-Mas ū $\overline{\text { ì, }}$, the reason that the attribute cannot be extended from the parts to the totality is that in the starting cases, Xs are infinite in number, so they cannot constitute an all-encompassing whole. By the same token, since in the case under discussion, the series of causes postulated too is infinite, there is no totality encompassing the entirety of causes, which could carry the attribute that each individual cause has.

The first case is the rotation of the heavenly spheres. Al-Mas'ū $\overline{\mathrm{u}}$ writes that, 'according to you' ('inda-kum), the series of heavenly rotations has no beginning and so is infinite a parte ante. Yet each individual rotation comes to be in time. However, as al-Mas'ūdī argues, Avicenna need not concede (lā yalzamu-kum) that this fact must be extended to the whole series of heavenly rotations, to infer that the series comes to be in time. The second case is that, according to Avicenna, human souls are infinite in number, as we have seen. And they have been infinite in number from pre-eternity, since there was never a particular point in time before which human souls were finite in number and at which they became infinite. Yet each individual human soul came to be in time. Avicenna, however, need not concede that this fact must be extended to the entirety of human souls, to infer that the whole, just like its individual units, came to be in time. According to al-Mas'ūdī, Avicenna need not concede these two implications: Avicenna is right not to appeal in either case to the notion that if all individual items of a set share an attribute, the same attribute may by extension be carried by the set as a whole, because in both cases the quantities in question are infinite and hence do not constitute wholes. Otherwise, if the rotations of a heavenly sphere do make up a whole, and if human souls likewise make up a whole, Avicenna will be forced to concede (lazima-kum bi-l-darūra) 
that both of these wholes have a beginning in time, just as their constituent units. Al-Mas'ū ūi concludes the section thus:

The truth of the matter is (al-tahqiq fi-hi) is what we have already stated, namely, that this [i.e. finitude] is entailed, neither with respect to [coexistent] causes, nor with respect to the separate souls, nor with respect to the rotations of the spheres. For their quantities do not terminate in a limit beyond which nothing of the same type exists, so much so that what is delimited [by it] would constitute a totality and a whole, and what applies to each individual would then apply to this totality. ${ }^{33}$

It goes without saying that al-Mas'ūdì himself subscribes to neither of these two Avicennan doctrines (that there has been an infinite number of successive heavenly rotations in the past, and that an infinite number of human souls exist), but invokes them as sound applications of the principle that motivates his discussion. As we have already seen, in Section 9 of the Shukūk, he argues against the theory of the pre-eternity of the world, which excludes the former of these two doctrines. ${ }^{34}$

An analogy such as the one put forth by al-Mas'ūdī requires proper correspondence between the two cases that form its starting point, on the one hand, and the case under discussion, on the other. Al-Mas'üdì does not establish this correspondence in detail, but deems the two sides of the analogy equivalent with respect both to $(a)$ the grounds on which the attribute of individual units extends to the whole, and $(b)$ the absence of a whole, when the units are infinite in number, to which any attribute could extend. He writes:

If it is possible for each one of an infinite number of souls to be preceded by a time at which it was nonexistent, whereas the entirety of these souls (in the sense of [their overall whole] ${ }^{35}$ ) is not preceded by a time at which it was nonexistent, then why would it not be possible for each one of an infinite number of causes to be preceded by a further cause from which it obtains existence, whereas the entirety of these causes (in the sense of [their overall whole]) is not preceded by a further cause from which it obtains existence? What difference is there between the two cases? ${ }^{36}$

\footnotetext{
33 Shukūk, 250.

34 See Section 3.5 above.

35 As opposed to their entirety, in the sense of 'each one, individually'.

36 Shukūk, 250.
} 
In al-Mas'üdī's view, therefore, the equivalence of the two sides of the analogy seems evident and in need of no further elaboration. He challenges his Avicennist adversaries to point out a difference ( farq) between them, which would render his analogy unsound. Pointing out a pertinent 'difference' between the original case and the secondary case is, of course, the most common way of countering an analogical argument (and we have already seen how al-Ghazālī demands the same: a difference between the original and secondary cases in his analogy).

Al-Mas'ūdì's objection seems to seize upon a point that Avicenna himself makes. We have seen how, to counter attacks on the notion of a beginningless series of successive things that come to be and pass away, Avicenna argues that such a series is not impossible because its units do not constitute a whole (jumla), since the units are not coexistent. ${ }^{37}$ What al-Mas ūdī does is to argue that the series is not impossible because it does not constitute a whole, since it is infinite.

The extant parts of al-Rāzìs Jawābāt do not include his commentary on Section 7 of the Shukük. ${ }^{38}$ But we would expect an Avicennist to respond to al-Mas'ūdì's analogy, not by taking up the challenge to delineate the difference between the original and secondary cases, but by rejecting the grounds on which he maintains that in the two original cases within his analogy the finitude of the series does not immediately follow from the finitude of its units. So while, to my mind, al-Mas üdì's central objection - that an infinite series cannot be treated as a self-contained whole, at least not in Avicenna's matterof-fact manner-seems quite compelling, there is much less mileage in his analogical ad hominem argument, as it fails to fulfil the principal requirement of this type of argument, namely, that it should start from the adversary's own views.

$37 \quad$ See Section 5.2 above.

38 The only work in which, to my knowledge, al-Rāzī discusses, and responds to, al-Mas'ūdī's objection is the Mațālib $(1,145 ; 149)$. 